\title{
Growing Imaginative Creativity of Students Through Video Making with The Brainstorming Method in History Learning
}

\author{
Kharista Setyo Nur Utami ${ }^{1},{ }^{*}$ Nana Supriatna ${ }^{2}$ Leli Yulifar ${ }^{3}$ \\ ${ }^{1}$ Students of the Master of History Education Program, Postgraduate School UPI \\ ${ }^{2}$ Lecturer in the Master of History Education Program, Postgraduate School UPI \\ ${ }^{3}$ Lecturer in the Master of History Education Program, Postgraduate School UPI \\ *Email: kharistasetyonur@gmail.com
}

\begin{abstract}
This study aims to look specifically at the brainstorming method and project based learning as historical learning methods to increase students imaginative creativity. This research uses the literature study method, namely by tracing reading sources in the form of books and journals, which later on the results of a study of various literatures will provide an explanation of the use of brainstorming methods and project based learning in history learning. The results from these sources found that imagination can develop well if teachers can facilitate students through a learning process that stimulates them to develop their imagination. The combination of project-based learning methods making creative videos with the brainstorming method can stimulate the imaginative power of vocational students. The implication of this research is that the video making project is relevant to the association and the tendency of today's vocational students who have an interest in making videos. So that the combination of the project based learning method with the brainstorming method facilitates the potential and talents of students who will ultimately be able to produce a creative and innovative product during the Covid-19 pandemic.
\end{abstract}

\section{Keywords: Imaginative Creativity, Video Making, Brainstorming, History Learning}

\section{INTRODUCTION}

Current history learning needs to pay attention to several competencies including aspects of knowledge, skills and attitudes. One of the skills to be achieved in current learning in the 2013 curriculum is creativity skills. The creativity developed in this research is imaginative creativity in history learning. The development of imaginative creativity in history learning requires the ability of teachers to facilitate students in using their potential to produce creative works [1].

The reality in the field that the researchers found when making observations at SMK class X TKJ (Computer and Network Engineering) shows that students creativity, innovation and motivation are still not optimal in history subjects. History learning tends to memorize more, coupled with the current condition of our nation which is affected by COVID-19, it has an impact on the learning process that must be done online. So that during the COVID-19 pandemic, teachers must be more innovative in the online learning process, so that students remain enthusiastic about learning and teachers must be able to create a pleasant learning atmosphere even though it is only online.

Another problem that was found was that the teacher had not been able to facilitate students in developing imaginative creativity, the teacher only used whatsapp media with the question and answer method, presentation and assignment, this showed that the teacher had not been innovative in the 
application of media and creative learning methods carried out online. This shows that the teacher is still conventional and does not arouse creative imaginative students. Conventional history learning will cause serious problems, considering that students are increasingly critical in the midst of developing information [2]. Learning methods such as discussion and question and answer sharpens students critical thinking but does not hone students creativity. This will cause boredom for students, if the method used by the teacher is monotonous.

Ratnasari, N.A.D., \& Winarti, M., (2020) also explained that the students 'lack of ability was due to the students' low reading interest in historical material [3]. Meanwhile, according to Supriatna, N (2019) that in history learning in Indonesia, traditional history teachers often use lecture skills with the aim that students enter the space where historical material is told. The teacher's storytelling skills can encourage students to develop their imaginative abilities [4].

Based on the problems found, it is necessary for the teacher to apply the students imaginative creativity. Researchers will develop creative and imaginative learning methods. In line with what Putro et al. (2018) explain that the creative learning method is the implementation of learning in the 2013 curriculum which has a positive effect on student achievement in developing 21 st century skills [5].

Through making videos with the brainstorming method in history learning. This method is a combination of the creative video creation project method with the brainstorming method. This method was chosen by researchers to suit the potential of students. The video made is a creative video where students can choose to make historical song lyrics or a role playing. Before making a creative video, students need to make a creative idea script. Then the design was submitted to friends through the brainstorming stage, after which a creative video was made.

Researchers hope that in the era of the Covid Pandemic 19, the methods the researchers will develop can be a solution to creating creative and imaginative historical learning. So that in the end an original work is created that combines the talents, interests and potential of students.

\section{METHOD}

This research method uses literature study with descriptive analysis. Harahap (2014) states that this method comes from books, encyclopedias, journals, dictionaries, magazines, documents, and so on. In looking at the problem, the researcher uses observation so that the researcher can formulate general problems in history learning at SMK. In addition, the sources that researchers use in examining this research come from books and journals [6].

\section{RESULT AND DISCUSSION}

\subsection{Imaginative Creativity in History Learning}

Conventional history learning aims to develop students imaginative abilities about the past. For historians, imaginations is a power to present the past to the time in which the reader is. Imagination is one of the strengths for someone to produce creative work. Likewise, in the aspect of learning at school. Creative teachers will use all their imaginations to develop original learning that characterizes themselves. Planned imagination as a trigger for the birth of creativity [1].

The ability imagination in history learning is needed to identify the basic elements of a narrative, and to develop the ability to describe the past based on the experiences of historical actors, historical literature, art, artifacts, and historical records from its time. Through this ability, students are expected to be able to explain past events from their knowledge and experience of historical maps, graphics, literature, music, art, or other data displays. According to Supriatna, N (2019), through imagination, students can become anyone or do anything (of course good) in their memory, thoughts or hopes [4].

According to Jung Re, (2016) states that imagination is a universal language, as something that is very close to human life with evidence that imagination can improve mental and physical coordination. The ability to imagine oneself doing activities in the future is an important aspect of creative cognition and creative achievement [7]. There are five components of creativity that describe the creative habits developed by Lucas \& Spencer (2017) as follows: inquisitive, imaginative, persistent, collaborative, and disciplined [8]. 


\subsection{Implementation of the Application of Making Video with the Brainstorming Method}

This study combines the brainstorming method with the project-based learning method where in the making of a project, a creative video is made through the brainstorming stage. The researcher combines the two methods on the basis that the two methods can foster students' imaginative creativity. This is evidenced by Syarifah \& Ramdhani, U., (2019) who explained that there is an influence of the brainstorming method in history lessons on the creativity of students[9]. In addition, Ratnasari, N.A.D., \& Winarti, W., (2020) also proved that the application of Project Based Learning in history subjects was proven to increase students' imagination skills [3]. According to Mackay in his book, he explains that the brainstorming method can be used to improve communication and referencing strategies for generating innovative ideas [10].

In addition, the application of the brainstorming method is a way to get lots of ideas from a group of people in a short way [11]. In this case, the time given to students to express their ideas is only during history lessons. The application of learning methods can run well, if supported by strengthening the ability of teachers to innovate to create interesting, creative, innovative, and fun learning [12].

According to Amin, D (2016) proves that using the brainstorming method can improve students ability to express their opinions or ideas in learning history [13]. As for making video projects according to Susanti, E (2019) proves that students will be more creative and motivated in learning history because in the process of making them students will be encouraged to find out deeper and be more creative in editing videos [14]. In line with what was developed by Adzandini \& Tarunasena (2019) that making video vlog projects with project-based learning can increase student creativity [15]. In contrast to this research, researchers will develop video making with the category of role playing or writing historical song lyrics to foster imaginative creativity.

Imaginative student creativity has some connection with the Project Based Learning model. First, the Project Based Learning model can increase student learning creativity. This is because, this model has learning stages that encourage students to plan, create, and deliver a project creatively. Second, the Project Based Learning model is able to encourage a variety of creative students in learning supported by sources of information that students can get. The sources of information obtained are the basis for them to create creative ideas which are then realized in an original project. Therefore, students need various sources of information either from the internet or books that can support their project development. Meanwhile, according to Balackova (2003), in an article entitled "Brainstorming: A Creative Problem-Solving Method". That the brainstorming method allows students to be more productive, creates a pleasant learning atmosphere and is able to foster student creativity [16]. As for the stages of the creative learning cycle according to Mitchell Resnick which are categorized into drawing activities, activities of creating, playing, sharing, reflecting, and returning to imagination, this learning can be referred to as Mitchell's Learning Spiral.

There are five stages of creative learning, the first stage is the initial stage. Imagination is a process of thinking about what to do or it can be called a brainstorming process. The next step, namely creation, is the root of creative learning. At this stage the students translate the ideas generated from the machining stage into the form of a product. For example, students develop creative video making skills. What makes this creative video consists of two categories of historical song lyric notes or role plays adapted to historical material. Role playing can make students into anyone [4].

Whereas in historical song lyrics, students will a singing from the results of the song lyrics they have made. According to Nela, E (2020) sings one of the strategies in conveying messages and impressions. Some teachers have taken advantage of this method, because various children at different ages enjoy listening to singing and learning by singing / songs because it can make the learning atmosphere fun so that it will grow into motivation in students [17].

This will also foster students grow imagination in designing song lyrics according to historical material. So what the students do is make a design in the form of a role playing script or a historical song lyric script. As for the making of historical song lyrics, the teacher has chosen a song with a national theme so that students only need to change the lyrics according to the history material. In making project design scripts, students can use the canva application to design their scripts to produce an imaginative creative script. Students who choose to role-play can 
use costumes and props that match the characters they play.

The next stage after creating is to play a game from the process of trying out a new creation or product that has been made and seeing whether the product is running well or not. In this case, what the researcher developed was to first present the results of a role playing or script song lyric through the brainstorming stage, to get additional ideas or creative ideas from his friends in order to perfect the results of the script that had been made.

Then the stage after playing is sharing, which is a process that shows the creations that have been made by and seeing what is thought about the creations made. In this case students will serve to present the video project that has been made. Students a make videos can use applications such as tiktok, kinemaster, powtoon etc. So that media technology that is currently close to the student environment can be used to produce work according to the interests and potential of students.

The last stage is the process of thinking about what has been learned from the creative experience then returning to the creative process to create new ideas after going through the process of creative activities. Reflection activities can be a part of each individual's evaluation of something that has been made and thought about. Below is an creative learning cycle [5]:

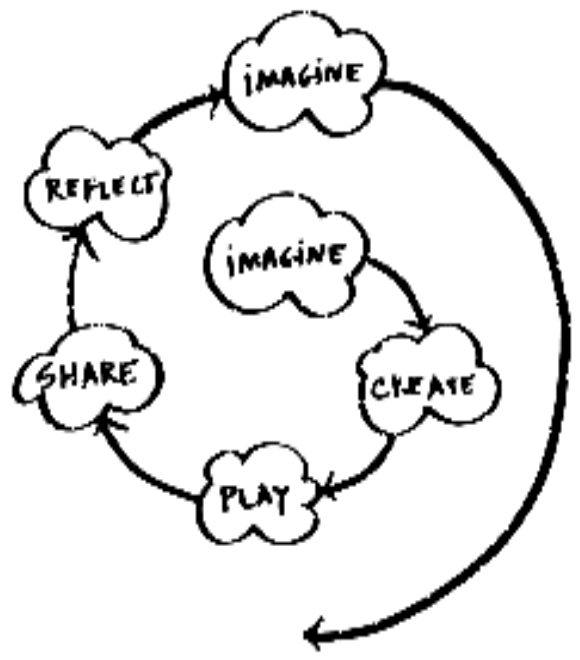

Figure 1 Creative Learning Cycle
Learning stages that will be developed by researchers through the brainstorming method will be the initial stage for students to dare to argue and spread ideas or ideas through brainstorming. The stages of making videos through the brainstorming method in this study including:

1. The teacher conveys the learning objectives and explains the method to be used

2. The teacher conveys the topic of material to be discussed, namely the Political and Economic Development of the Reformation Period in the form of a learning video

3. The teacher presents the problems and tasks that need to be done, namely making creative videos, where there are two categories in making products including the category of making historical song lyrics or role playing. Students only choose one category.

4. The teacher provides material distribution that can be used as song lyrics or role playing which can then be developed by students themselves from relevant sources.

5. Next, students design creative ideas and then put them in written form

6. After finishing designing the product, students share the design through Google Classroom and the teacher also evaluates the results of the design.

7. Students can provide comments or opinions on the results of their friends' designs the product, at least 1 person and a maximum of 3 people from the designs product of their friends with different material themes

8. After going through the brainstorming stage, the teacher asks students to proceed to the videomaking stage

9. The teacher will choose the 6 best videos to present and the other friends are tasked with providing responses in the form of comments or additions or may also be in the form of questions.

10. The next stage is the presentation of the project that has been made, and discussion using the brainstorming method.

11. Finally, the teacher and students conclude and reflect on the material and the results of the creative projects that have been made. 
The indicators of the ability for imaginative creativity through making videos developed in this study, namely students can:

Table 1. Indicators of students imaginative creativity through video making with the brainstorming method

\begin{tabular}{|c|c|c|}
\hline Component & Indicator & Sub Indicator \\
\hline \multirow[t]{5}{*}{ Imaginative Creativity (Process) } & \multirow[t]{2}{*}{ Skilled in abstract thinking } & $\begin{array}{l}\text { High curiosity about the relevance of each } \\
\text { information is shown by reading the narrative / } \\
\text { material }\end{array}$ \\
\hline & & $\begin{array}{l}\text { Able to identify facts and causes and effects of } \\
\text { a phenomenon from relevant sources }\end{array}$ \\
\hline & \multirow[t]{2}{*}{$\begin{array}{l}\text { The ability to offer imaginative } \\
\text { solutions or possibilities }\end{array}$} & $\begin{array}{l}\text { Synthesize, analize, imagine and combine } \\
\text { different things into something new }\end{array}$ \\
\hline & & $\begin{array}{l}\text { Use intuition to develop thoughts about what to } \\
\text { learn or connect with something new }\end{array}$ \\
\hline & Collaborative Ability & The ability to share ideas or ideas with others \\
\hline \multirow[t]{4}{*}{$\begin{array}{l}\text { Imaginative Creativity (Making } \\
\text { Video Products) }\end{array}$} & \multirow[t]{2}{*}{ Novelty } & $\begin{array}{l}\text { Students are able express opinions/ new ideas, } \\
\text { original ideas by using words own }\end{array}$ \\
\hline & & $\begin{array}{l}\text { Students have the ability to produce creative, } \\
\text { imaginative and innovative products }\end{array}$ \\
\hline & \multirow{2}{*}{ Skilled in expressing } & $\begin{array}{l}\text { Students are able to produce a work from what } \\
\text { has been planned }\end{array}$ \\
\hline & & $\begin{array}{l}\text { Students are able to explain their work } \\
\text { confidently }\end{array}$ \\
\hline
\end{tabular}

Based on the indicators of creativity imagination through a making video above, it can be seen that there is a match between the indicators that have been determined by coming from project based learning and brainstorming. The characteristics of project based learning focus on making the meaning of each learning process carried out by students, namely starting from making decisions, frameworks, evaluating activities continuously, so as to make the final result in the form of a product to make creative videos that have been assessed for quality according to their respective understandings each individually.

If applied with the indicators above, it can be seen that the project based learning is compatible with the Imaginative creativity indicator combined with the brainstorming method. Where in the best ability, the end goal is to be able to produce a work that has been planned. The selected work is an agreement between teachers and students. Meanwhile, the brainstorming method refers to extracting ideas based on students creative thinking through ideas.

\section{CONCLUSION}

Students imaginative creativity will be formed if the learning process provides that space. Teachers should facilitate students to be able to develop their imaginative creativity. In the hands of creative teachers using creative methods will be able to facilitate students to imagine. In this study, a projectbased learning method for creating creative videos was developed in which it was divided into two categories, namely role playing or writing historical song lyrics, combined with the brainstorming method.

Combining these two methods into one unit will be an alternative for teachers in fostering students' imaginative creativity. In the era of information and communication technology where historical learning resources are abundant, teachers and students have the opportunity to teach and learn history creatively.

Technology that is currently so close to students is expected to be used by students as best as possible to explore their potential and interests so that they can produce creative work. Making videos with the brainstorming method will stimulate the students' imaginative creativity because in the process of making them students will be encouraged to find out deeper and be more creative in editing videos with the theme of the history material.

\section{ACKNOWLEDGMENTS}

The author to thanks Prof. Dr. Nana Supriatna M.Ed and Mrs. Dr. Leli Yulifar, M.Pd as the Lecturer of the UPI History Education Masters Program who has helped, provided guidance, direction and to beloved mothers and fathers for prayers, helped and support. 


\section{REFERENCES}

[1] Supriatna, N. \& Maulidah, N.: Pedagogi Kreatif : Menumbuhkan Kreativitas dalam Pembelajaran Sejarah dan IPS. PT Remaja Rosdakarya, Bandung (2020)

[2] Yulifar, L.: Teacher's Effort in Improving Historical Writing Skill by Presenting Historian as Resources Person on Historical Learning. Advances in Social Education and Humanities Research 1 st International Conference of Innovation in Education (ICoIE): Atlantis Press. Vol.178. 230-234 (2018)

[3] Ratnasari, N.A.D., dan Winarti, W.: Project based learning untuk meningkatkan kemampuan imajinasi siswa dalam pembelajaran sejarah. FACTUM: Jurnal Sejarah dan Pendidikan Sejarah, Vol. 1. 11-14 (2020)

[4] Supriatna, N.: Pengembangan Kreativitas Imajinatif Abad ke-21 dalam Pembelajaran Sejarah. Jurnal Pendidik dan Peneliti Sejarah. Vol. 2, No. 2. 73-82 (2019)

[5] Putro,dkk.: Creative Learning Model as Implementation of Curriculum 2013 to Achieve $21^{\text {st }}$ Century Skills. Journal of Physics. (2019)

[6] Harahap, N.: Penelitian Kepustakaan. Jurnal Iqra'. Vol 1, No. 8 (2014)

[7] Jung Re, Flores RA, dan Hunter D.: A New Measure of Imagination. Ability: Anatomical Brain Imaging Correlates. Journal Frontiers in Psychology. Mexico, USA (2016)

[8] Lucas, D., \& Spencer, E.: Teaching Creative Thingking, Developing Learnes who Generate Ideas and Can Think Critically. Continum, London (2017)

[9] Syarifah \& Ramadhani, U.: Pengaruh Model Brainstorming Pada Pembelajaran Sejarah Terhadap Kreativitas Siswa Di Kelas X Smk Swasta Al Washliyah Pasar Senen 2 Medan. Jurnal. Vol. 1 (2019)

[10] Mackay, W.: Video Techniques for Participatory Design: Observation, Brainstorming \& Prototyping. Department of Computer Science Aarhus University Aabogade, Denmark (2000)

[11]Balackova, H.: Brainstorming: A Creative Problem-Solving Method. (2003)

[12] Rawlinson, JG.: Berpikir Kreatif dan Brainstorming. Erlangga, Jakarta (1977)

[13] Darmawan, W., Kurniawati, Y., Rusmiati, D.: Penerapan pembelajaran edutainment model if history dalam program penugasan dosen (PDS) di SMAN 8 Bandung. FACTUM: Jurnal Pendidik dan Peneliti Sejarah. Vol.1. 33-38 (2020)

[14]Amin, D.: Penerapan Metode Curah Gagasan (Brainstorming) Untuk Meningkatkan Kemampuan Mengemukakan Pendapat Siswa. Jurnal Pendidikan Sejarah. Vol. 2 (2016)
[15] Susanti,E. : Project Based Learning: Pemanfaatan Vlog Dalam Pembelajaran Sejarah Untuk Generasi Pro Gadget. Jurnal Sejarah, Budaya dan Pengajaran. 85-96 (2019)

[16] Adzandini \& Tarunasena.: Proyek Vlog Untuk Meningkatkan Kreativitas Siswa Dalam Pembelajaran Sejarah. FACTUM: Jurnal Pendidik dan Peneliti Sejarah. 337-246 (2019)

[17] Nela, E.: Implementasi Teknologi Digital Untuk Meningkatkan Karakter Kejujuran Dan Motivasi Belajar Peserta. Jurnal Historia (2020) 